\title{
Antibiotic Resistant Pattern and Resistant Gene Identification of Staphylococcus aureus from Chicken Farm in Bogor
}

\author{
(POLA RESISTANSI ANTIBIOTIK DAN IDENTIFIKASI GEN RESISTANSI \\ PADA STAPHYLOCOCCUS AUREUS DARI PETERNAKAN AYAM DI BOGOR) \\ Nabila Swarna Puspa Hermana, Usamah Afiff, Safika, \\ Agustin Indrawati, I Wayan Teguh Wibawan, Fachriyan Hasmi Pasaribu* \\ Division of Medical Microbiology \\ Department of Animal Disease and Veterinary Public Health \\ Faculty of Veterinary Medicine, IPB University \\ Jl. Agatis, IPB Dramaga Campus, Bogor, \\ West Java, Indonesia 16880 \\ (+62-251) 8629469; *Email: fhpasaribu@gmail.com
}

\begin{abstract}
Chicken is one of the important protein source in Indonesia. Moreover, the largest population of chicken layer and poultry in Indonesia is known situated at West Java province with Bogor manicipality as the main producer. The aims of this study were to determine the antibiotic resistance pattern of Staphylococcus aureus isolated from poultry and layer farm in Bogor. The study also identified gene encoded the resistance. Cloacal swab samples were collected from chicken broiler and layer farm in Bogor manicipality. The samples were then cultured in Mannitol Salt Agar (MSA) medium to obtain S. aureus. Suspected colony was then confirmed by biochemical test. Positive strains were tested against several antibiotics and the diameter of clear zone arround of colony was interpreted based on Clinical and Laboratory Standard Institute. Furthermore, the DNA from resistant strains were then extracted, followed by detection of the resistance gene by using polymerase chain reaction (PCR) method. A total of 14 isolates of S. aureus were positive from poultry farm, and 15 isolates from layer farm. Most of all were resistant to tetracycline, ampicillin, oxytetracycline, erythromycin and nalidixic acid. On the other hands, several strains were sensitive to gentamycin and chloramphenicol. The study showed 28 isolates out of them were multi-drug resistant. Resistant gene such as blaTEM, gyrA and tetA were also identified in some isolates except for ErmB gene which was found in isolates originated from poultry farm. In conclussion, S. aureus in both farm showed mostly multi-drug resistant to several antibiotics which were supported by identification of resistant gene among isolates.
\end{abstract}

Keywords: antibiotic; chicken; resistant gene; S. aureus

\begin{abstract}
ABSTRAK
Ayam merupakan salah satu sumber protein penting di Indonesia. Provinsi Jawa Barat memiliki populasi ayam pedaging dan petelur terbesar di Indonesia, dan Bogor sebagai daerah dengan populasi tertinggi. Tujuan penelitian ini adalah untuk menentukan pola resistensi antibiotik pada Staphylococcus aureus yang diisolasi dari peternakan ayam pedaging dan petelur serta mengidentifikasi gen resistansinya. Sampel usap kloaka dari peternakan ayam pedaging dan petelur dibiakkan pada medium Mannitol Salt Agar (MSA) untuk memperoleh $S$. aureus dan diteguhkan menggunakan uji biokimiawi. Isolat positif $S$. aureus diuji resistansinya terhadap beberapa antibiotik dan zona hambat yang terbentuk ditafsirkan berdasarkan Clinical and Laboratory Standard Institute. Senyawa DNA dari isolat resistan diekstraksi dan dilacak keberadaan gen resistansinya dengan polymerase chain reaction (PCR). Sebanyak 14 isolat $S$. aureus diperoleh dari peternakan ayam pedaging dan 15 isolat diperoleh dari peternakan ayam petelur. Sebagian besar isolat dari kedua peternakan resistan terhadap tetrasiklin, ampisilin, oksitetrasiklin, eritromisin dan asam nalidiksat. Isolat masih peka terhadap gentamisin dan kloramfenikol. Sebanyak 28 isolat dari kedua peternakan tahan terhadap beberapa antibiotik (multidrug resistant) karena
\end{abstract}


mengalami resistansi terhadap lebih dari tiga jenis antibiotik. Gen resistansi seperti blaTEM, gyrA, dan tetA ditemukan di kedua peternakan, sedangkan gen ermB hanya ditemukan di peternakan ayam pedaging. Bakteri $S$. aureus dari kedua peternakan tahan terhadap beberapa antibiotik dan memiliki gen resistansi terhadap antibiotik pada isolat resistan.

Kata-kata kunci: antibiotik; ayam; gen resistansi; S. aureus

\section{INTRODUCTION}

Chicken was one of favourite protein source in Indonesia since its easiness to find and cheap price. West Java province has known as the largest chicken population in Indonesia with total population $644,923,955$ chicken in 2018 (Disnak Jabar, 2018). Moreover, Bogor regency is the central of poultry chicken production in West Java with poultry chicken population in Bogor regency was 19,062,875 heads in 2018 . West Java province also has known as the largest layer population with $14,469,405$ chicken in 2018. Largest population of layer chicken also found in Bogor regency with 4,826,000 heads in 2018 (Ditjen PKH, 2018).

Staphylococcus aureus is an opportunistic pathogen in human and animal. It considered as the third most common pathogen caused food poisoning in the world (Kadariya et al., 2014). The species caused several diseases in poultry it associated with several diseases, such as staphylococcosis, osteomyelitis, arthritis, and bumble foot disease (Giedraitiene et al., 2011). The agents can be transmitted via feed, litter, water, and may also be transmitted transovarially (Hakkani et al., 2016).

Antibiotic was widely used for fight the infection caused by $S$. aureus, such as penicillin, erythromycin, and tetracycline. Unfortunately, farmers also used antibiotic in poultry as a prophylaxis and growth promotor. However, the use of extensive antibiotic with improper procedure can promote the increasing of antibiotic resistant bacteria (Wongsuvan et al., 2018). It is known most $S$. aureus strains are heterogeneously resistant to several antibiotic such as beta-lactams, aminoglycosides, macrolides, clindamycin and tetracycline. Erythromycin, tetracycline and penicillin-G were few antibiotic used to treat infection in poultry (Ali et al., 2017). Staphylococcus aureus was resistant to most used antibiotic. In the last decade, public are concerning about antibioticresistance (Khodadadi et al., 2016).

The aim of this research was to identify the pattern of antibiotic resistance in chicken broiler and layer at Bogor regency. The research also detected the gene encoded the antibiotic resistance in S. aureus.

\section{RESEARCH METHODS}

\section{Isolation and Identification of S. aureus}

Cloacal swab samples were collected from chicken broiler and layer farm in Bogor regency and stored them in phosphate buffered saline (PBS) until processed in laboratorium. Samples were cultured in mannitol salt agar (MSA) and incubated at $37^{\circ} \mathrm{C}$ for 24 hours. Staphylococcus aureus colony ferment mannitol and changed the medium color from red to yellow. The suspected colony was identified according to Indonesian National Standard for S. aureus identification number SNI 2332.9-2011. The test initiated by Gram staining, catalase test, coagulase test, and glucose fermentation microaerophilic (SNI, 2011). The deoxyribonucleic acid (DNA) material was extracted from positive isolate using PrestoTM Mini gDNA Bacterial kit (Geneaid) based on manufacturer guidance. Staphylococcus aureus specific femA was detected by polymerase chain reaction (PCR) using forward primer $5^{1}$ - GCAAACTGTTGGCCACTATG $-3^{1}$ and reverse primer $5^{1}$ - TCATCACGATCA GCAAAAGC $-3^{1}$ with its 594 bp amplicon (RiyazUl-Hassan et al., 2008).

\section{Antibiotic Susceptibility Test}

Isolate of $S$. aureus was tested against several antibiotics based on Kirby-Bauer disk diffusion method. Staphylococcus aureus were suspended in $\mathrm{NaCl}$ solution until its density reached McFarland 0.5 and then cultured on Mueller-Hinton agar (MHA) plate. Antibiotic disks were placed on cultured MHA and incubated in $37^{\circ} \mathrm{C}$ for 24 hours. Tetracycline $(30 \mu \mathrm{g})$, oxytetracycline $(30 \mu \mathrm{g})$, ampicillin (10 $\mu \mathrm{g})$, gentamycin $(30 \mu \mathrm{g})$, nalidixic acid $(30 \mu \mathrm{g})$, enrofloxacin $(5 \mu \mathrm{g})$, ciprofloxacin $(5 \mu \mathrm{g})$, chloramphenicol $(5 \mu \mathrm{g})$, and erythromycin $(15$ $\mu \mathrm{g})$ were used for this test. The diameter of inhibition zone were measured and then 
interpreted according to the Clinical and Laboratory Standard Institute (CLSI) 2018 (CLSI, 2018).

\section{Identification of Resistance Gene}

The DNA of resistant strain were extracted by PrestoTM Mini gDNA Bacterial Kit (Geneaid) and it were detected by single PCR method. Total volume of PCR reaction mix was $50 \mu \mathrm{L}$ containing $3 \mu \mathrm{L}$ of DNA template, $25 \mu \mathrm{L}$ of PCR mix, $2 \mu \mathrm{L}$ of $10 \mathrm{pm}$ forward primer, $2 \mu \mathrm{L}$ of 10 pm reverse primer, and $18 \mu \mathrm{L}$ of $\mathrm{dd}_{2} \mathrm{O}$ (Table 1). Polymerase chain reaction was performed using a thermocycler (Biorad) with five minutes of initial denaturation at $95^{\circ} \mathrm{C}$, followed by 30 cycle of denaturation at $95^{\circ} \mathrm{C}$ for 30 seconds, annealing for one minute, extension at $72^{\circ} \mathrm{C}$ for one minutes, and final extension at $72^{\circ} \mathrm{C}$ for 10 minutes. Polymerase chain reaction product were analysed on $1 \%$ agarose gel electrophoresis and were analysed under UV-transiluminator after florosafe gel staining was added to the gel.

Table 1. Primers used in this study affect to human health, and leads to food borne diseases (Ribeiro et al., 2018). Staphylococcus aureus was often colonized on skin and mucous membrane in human and animals (Khodadadi et al., 2016). In chicken, it caused several diseases such as staphylococcosis, osteomyelitis, arthritis, and bumble foot disease (Giedraitiene et al., 2011). Infection which caused by $S$. aureus usually treated by antibiotics. The frequently using antibiotic to treat $S$. aureus infection is penicillin, erythromycin, and tetracycline (Ali et al., 2017). Increasing of antibiotic use in chicken broiler and layer farm, increasing number of resistant $S$. aureus strain (Netsvyetayeva et al., 2014). Staphylococcus aureus has an outstanding ability to acquire resistance to antibiotics, which is considered a major public health concern (Fernandez et al., 2012; Meemken et al., 2013).

The antibiotic susceptibility test result presented in Table 2. According to Table 2, $S$. aureus were isolated from chicken broiler farm were resistant to erythromycin and ampicillin

\begin{tabular}{|c|c|c|c|c|}
\hline Gene & Sequence base & $\begin{array}{l}\text { Amplicon } \\
\text { (bp) }\end{array}$ & $\begin{array}{l}\text { Annealing } \\
\left({ }^{\circ} \mathrm{C}\right)\end{array}$ & Reference \\
\hline GyrA & $\begin{array}{l}\text { (F) } 5^{1} \text { ATGAGCGAATTAGCCAAAGA } 3^{1} \\
\text { (R) } 5^{1} \text { GCAACCGTCCAACACTTCAT } 3^{1}\end{array}$ & 582 & 62 & Wang et al., 2010 \\
\hline tetA & $\begin{array}{l}\text { (F) } 5^{1} \text { CGACCTTGCGAGAGAAAT } 3^{1} \\
\text { (R) } 5^{1} \text { GTTCCATCAGCCCTTCAA } 3^{1}\end{array}$ & 965 & 62 & Chuah et al., 2018 \\
\hline blaTEM & $\begin{array}{l}\text { (F) } 5^{1} \text { ATCAGCAATAAACCAGC } 3^{1} \\
\text { (R) } 5^{1} \text { CCCCGAAGAACGTTTTC } 3^{1}\end{array}$ & 516 & 54 & Colom et al., 2003 \\
\hline ermB & $\begin{array}{l}\text { (F) } 5^{1} \text { GAAAAGGTACTCAACCAAATA } 3^{1} \\
\text { (R) } 5^{1} \text { GTAACGGTACTTAAATTGTTTAC } 3^{1}\end{array}$ & 639 & 54 & Song et al., 2004 \\
\hline
\end{tabular}

\section{RESULTS AND DISCUSSION}

A total of 79 samples were collected from chicken broiler and layer farm, which are 49 samples were collected from chicken broiler farm and 30 samples were obtained from layer farm. Fourteen (28\%) isolates from chicken broiler farm and $15(50 \%)$ from layer farm were identified as $S$. aureus using biochemical test and molecular examination of $f e m A$. FemA gene is a specific gene in $S$. aureus which encoded a $48 \mathrm{kDa}$ protein on cell wall synthesis. The presented femA gene was detected by PCR (Figure 1) (Khodadadi et al., 2016).

The presence of $S$. aureus in poultry is important in food poultry industry since it may

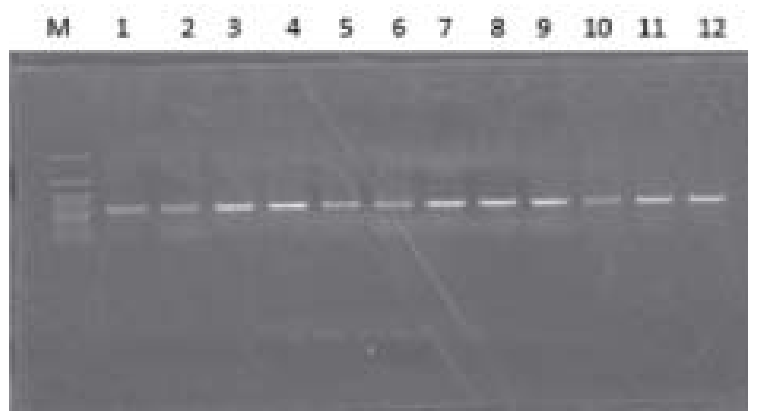

Figure 1. Polymerase Chain Reaction/PCR result of femA gene after electrophoresis (594bp). Lane M: marker (100bp); lane 1 to 6: samples from poultry farm; lane 7 to 10: samples from layer farm in Bogor 
chloramphenicol (13\%). No isolate were resistant to gentamycin.

Similar result showed that $S$. aureus, were isolated from chicken in Nigeria and Bangladesh were $100 \%$ resistant to erythromycin and tetracycline (Ali et al., 2017; Onaolapo et al., 2017). Antibiotic used in this study were commonly used by farmer in Indonesia (Zalizar et al., 2015). Most common antibiotic used in chicken farm were erythromycin, tetracycline, penicillin, and doxycycline. Staphylococcus aureus in this study was least resistant to gentamycin and chloramphenicol, which is least used antibiotics in poultry. Similar result also occurred in Yogyakarta Indonesia and Kaduna, Nigeria where $26,1 \%$ and $3,1 \%$ of $S$. aureus were be resistant to gentamycin respectively (Khusnan et al., 2016; Onaolapo et al., 2017).

Antibiotics are being used in poultry industry in order to prevent bacterial infection on poultry, along with strict biosecurity and hygiene (Bermudez, 2003). Intensive chicken broiler farming in North America often use antibiotics such as tetracycline, bacitracin, tylosin, salinomycin, virginiamycin and bambermycin (Diarra and Malouin, 2014). Tetracyclines is used more than two-thirds of antimicrobials administered to animals (Ronquillo and Hernandez, 2017) in North America and only 37\% in European Union (Carvalho and Santos, 2016). Using antibiotics as growth promotors have been banned by Indonesian Goverment since 2018 in order to minimize negative impact of antibiotics (Ditjen PKH, 2018).

Staphylococcus aureus, were isolated from both chicken broiler and layer farm, were be resistant to more than three antibiotics so it considered as multi-drug resistant. One isolate, was isolated from poultry farm was be resistant to all antibiotic tested, while the highest number of resistant pattern was TE-OT-AMP-NA-ENRCIP-E where four isolate were be resistant. One isolate, isolated from layer farm was be resistant to eight antibiotics. Highest number of resistant pattern was TE-OT-AMP-NA-ENR-CIP-E where five isolate were be resistant (Table 3).

Multi-drug resistant species is species that is resistant to three, or more than three antibiotics (Bianchi et al., 2014). The research result showed only one of 29 isolate was not as a multi-drug resistant species. The similar result was showed with study in Zagazig, Egypt and Karaj, Iran, that stated $S$. aureus from meat product poultry were multi-drug resistant
(Morshdy et al., 2018; Nouri-Gharajalar et al., 2019).

Multi-drug resistance bacteria is important issue in public health because it exist in animals, humans, and environment. The antibiotic resistance caused by excesive use of antibiotics in animals and humans. Another factors such as antibiotics trading, increased international travels, poor sanitation and hygine, and antibiotics residue released into the environment contributes to the antibiotic resistance. Those factors also contribute to existence of multidrug resistant strain (Aslam et al., 2018).

Ten isolates (six samples from chicken broiler and four samples from layer farm) were analysed by PCR amplification method using primer to detect resistance gene (Table 1). GyrA, tet $A$, blaTEM, and ermB genes were detected in six isolates of broiler farm (Table 4). GyrA and blaTEM gene were detected in four isolates of layer farm, tet $A$ gene was detected in three isolates, meanwhile erm $B$ was not found in layer farm sample (Figure 2-5).

All samples from poultry and layer farm have blaTEM gene. The similar result showed in Iran and Taiwan where $100 \%$ beta lactamase resistant strain have a blaTEM gene (Yang et al., 2017; Nouri-Gharajalar et al., 2019). BlaTEM gene encodes most encountered bacteria â-lactamase (Xu et al., 2014). Most strains, which have blaTEMgene, exhibited a high degree of resistance to â-lactam antibiotics in China and Taiwan (Yang et al., 2017). Modifcation of penicillin-binding protein (PLP2a) induces inactivity of penicillin and other beta lactam antibiotics; and it will develop cross-resistance of multiple antibiotics (Bounar-Kechih et al., 2018).

GyrA gene also found in ten $S$. aureus from both farm. The similar gene has been detected in S.aureus isolated from Spanish hospital (Lozano et al., 2018). The other research reported that quinolones-resistant $S$. aureus isolates, were isolated from clinical and soil sources, had independent alleles of gyrA (de Vries et al., 2009). Mutation in gyr $A$ is responsible for mutation that occurred in quinolone-resistance S. aureus, where the mutation occurred at codon 83 or 87 (Zhao et al., 2018). Further sequencing needed to determine the mutational site in this study.

Although tet $M$ and tet $K$ were common genes conferring tetracycline resistance in $S$. aureus (de Vries et al., 2009), the research showed tetA gene was found in nine isolates. The previous 
Table 2. Antibiotic resistant pattern of Staphylococcus aureus isolate from broiler and layer farm in Bogor

\begin{tabular}{lllll}
\hline \multirow{2}{*}{ Antibiotic } & Sample & \multicolumn{3}{c}{ Interpretation of clear zone } \\
\cline { 5 - 5 } & source & Susceptible $n(\%)$ & Intermediate $n$ (\%) & Resistance $n(\%)$ \\
\hline Tetracycline $(30 \mu \mathrm{g})$ & $\mathrm{PF}$ & $1(7)$ & $0(0)$ & $13(93)$ \\
& $\mathrm{LF}$ & $0(0)$ & $0(0)$ & $15(100)$ \\
Oxytetracycline $(30 \mu \mathrm{g})$ & $\mathrm{PF}$ & $1(7)$ & $0(0)$ & $13(93)$ \\
& $\mathrm{LF}$ & $0(0)$ & $0(0)$ & $15(100)$ \\
Ampicillin $(10 \mu \mathrm{g})$ & $\mathrm{PF}$ & $0(0)$ & $0(0)$ & $14(100)$ \\
& $\mathrm{LF}$ & $0(0)$ & $0(0)$ & $15(100)$ \\
Gentamycin $(30 \mu \mathrm{g})$ & $\mathrm{PF}$ & $11(79)$ & $0(0)$ & $3(21)$ \\
& $\mathrm{LF}$ & $15(100)$ & $0(0)$ & $0(0)$ \\
Nalidixic acid $(30 \mu \mathrm{g})$ & $\mathrm{PF}$ & $0(0)$ & $1(7)$ & $13(93)$ \\
& $\mathrm{LF}$ & $0(0)$ & $0(0)$ & $8(57)$ \\
Enrofloxacin $(5 \mu \mathrm{g})$ & $\mathrm{PF}$ & $1(7)$ & $5(36)$ & $11(73)$ \\
& $\mathrm{LF}$ & $4(27)$ & $0(0)$ & $8(57)$ \\
Ciprofloxacin $(5 \mu \mathrm{g})$ & $\mathrm{PF}$ & $4(29)$ & $2(14)$ & $6(40)$ \\
& $\mathrm{LF}$ & $4(27)$ & $5(33)$ & $14(100)$ \\
Erythromycin $(15 \mu \mathrm{g})$ & $\mathrm{PF}$ & $0(0)$ & $0(0)$ & $15(100)$ \\
& $\mathrm{LF}$ & $0(0)$ & $0(0)$ & $5(36)$ \\
Chloramphenicol $(5 \mu \mathrm{g})$ & $\mathrm{PF}$ & $7(50)$ & $2(14)$ & $2(13)$ \\
& $\mathrm{LF}$ & $13(87)$ & $0(0)$ &
\end{tabular}

Note: $\mathrm{PF}=$ Poultry farm; $\mathrm{LF}=$ Layer farm

Table 3. Multi-drug resistant pattern of Staphylococcus aureus isolate from poultry and layer in Bogor

\begin{tabular}{llll}
\hline $\begin{array}{l}\text { Origin of } \\
\text { samples }\end{array}$ & $\begin{array}{l}\text { No of antibiotic } \\
\text { resistant }\end{array}$ & Antibiotics & $\begin{array}{l}\text { No of resistant } \\
\text { isolate }(\%)\end{array}$ \\
\hline Poultry & 9 & TE-OT-AMP-CN-NA-ENR-CIP-E-C & $1(7,14)$ \\
& 8 & TE-OT-AMP-NA-ENR-CIP-E-C & $2(14,28)$ \\
& 7 & TE-OT-AMP-CN-NA-CIP-E & $1(7,14)$ \\
& 7 & TE-OT-AMP-NA-ENR-CIP-E & $4(28,57)$ \\
& 7 & TE-OT-AMP-NA-ENR-E-C & $1(7,14)$ \\
& 6 & TE-OT-AMP-CN-NA-E & $1(7,14)$ \\
& 5 & TE-OT-AMP-E-C & $1(7,14)$ \\
Layer & 5 & TE-OT-AMP-NA-E & $2(14,28)$ \\
& 8 & AMP-NA-E & $1(7,14)$ \\
& 7 & TE-OT-AMP-NA-ENR-CIP-E-C & $1(6,67)$ \\
& 7 & TE-OT-AMP-NA-ENR-CIP-E & $5(33,33)$ \\
& 6 & TE-OT-AMP-NA-ENR-E-C & $1(6,67)$ \\
& 5 & TE-OT-AMP-NA-ENR-E & $4(26,67)$ \\
& & TE-OT-AMP-NA-E & $4(26,67)$ \\
\hline
\end{tabular}

(100\%); tetracycline, oxytetracycline, and nalidixic acid (93\%); enrofloxacin and ciprofloxacin (57\%); chloramphenicol (36\%); and gentamycin (21\%). Meanwhile, S. aureus were isolated from layer farm were resistant to tetracycline, oxytetracycline, ampicillin, nalidixic acid, and erythromycin (100\%); enrofloxacin (73\%); ciprofloxacin (40\%); and 
Table 4. Number of resistant gene found in Staphylococcus aureus isolate [n (\%)]

\begin{tabular}{lll}
\hline Resistant gene & Poultry farm & Layer farm \\
\hline GyrA & $6(100)$ & $4(100)$ \\
tet $\mathrm{A}$ & $6(100)$ & $3(75)$ \\
BlaTEM & $6(100)$ & $4(100)$ \\
ermB & $6(100)$ & $0(0)$ \\
\hline
\end{tabular}

\section{$\begin{array}{lllllllllll}M & 1 & 2 & 3 & 4 & 5 & 6 & 7 & 8 & 9 & 10\end{array}$}

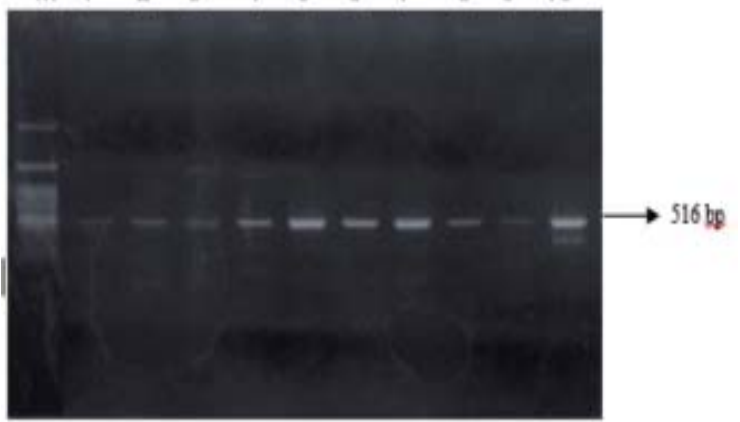

Figure 2. Polymerase Chain Reaction/PCR result of blaTEM gene after electrophoresis. Lane M: marker (100bp); lane 1 to 6: samples from poultry farm; lane 7 to 10: samples from layer farm in Bogor

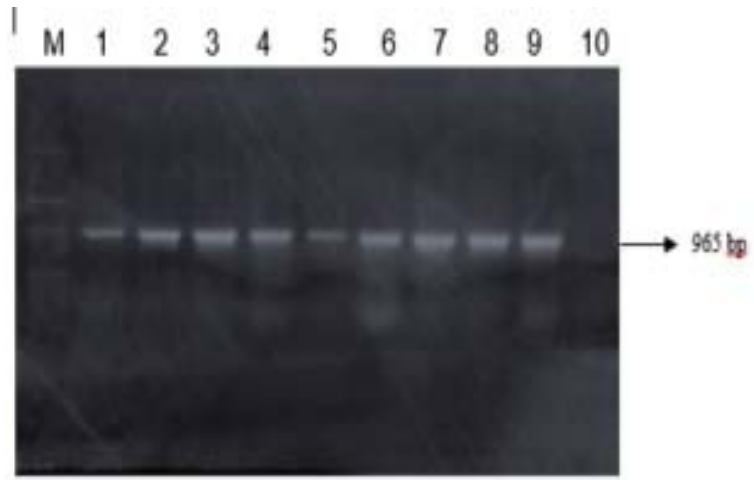

Figure 4. Polymerase Chain Reaction/PCR result of tetA gene after electrophoresis. Lane M: marker (100bp); lane 1 to 6: samples from poultry farm; lane 7 to 10: samples from layer farm in Bogor

studies showed that $21-96 \%$ of tetracycline resistant bacteria possessed the tet $M$ and tet $A$ genes, suggesting that both genes are a significant contribution to the tetracycline resistant (Liyanage et al., 2018). Tetracycline resistance genes are often associated with conjugative and mobile genetic elements enabling horizontal transfer (Dayao et al., 2016)

$\operatorname{ErmB}$ gene was only detected in $S$. aureus isolates that were isolated form chicken broiler farm. Study in Kerman, Iran showed that 20.5\% of $S$. aureus isolates that were isolated from clinical sample has ermB gene (Fasihi et al., 2016). $\operatorname{Erm} B$ is one of common gene encoded resistant to erythromycin and responsible for

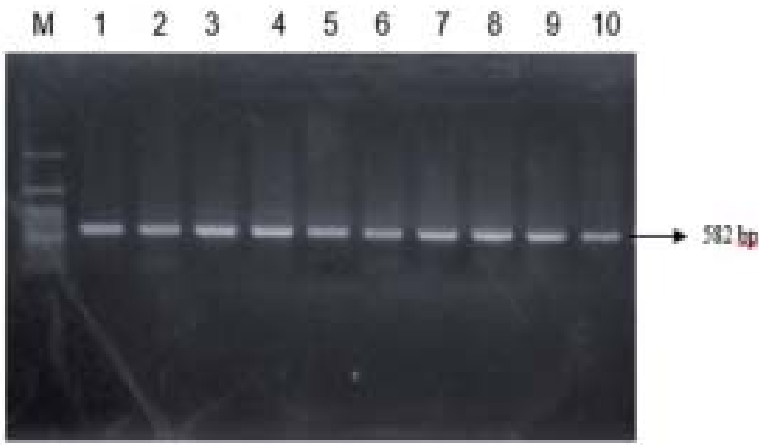

Figure 3. PCR result of gyrA gene after electrophoresis. Lane M: marker (100bp); lane 1 to 6: samples from poultry farm; lane 7 to 10 : samples from layer farm in Bogor
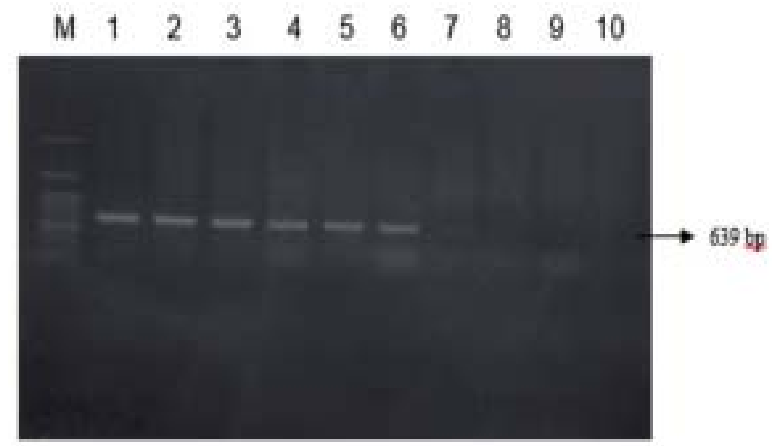

Figure 5. Polymerase Chain Reaction/PCR result of ermB gene after electrophoresis. Lane M: marker (100bp); lane 1 to 6: samples from poultry farm; lane 7 to 10: samples from layer farm in Bogor

ribosomal binding site modifications that are the most important macrolide resistance mechanisms (Takaya et al., 2010, Zmantar et al., 2011). 


\section{CONCLUSION}

Staphylococcus aureus isolates were isolated from chicken broiler and layer in Bogor Regency have resistant to erythromycin, ampicillin, tetracycline, oxytetracycline, nalidixic acid, enrofloxacin and ciprofloxacin, and sensitive to chloramphenicol gentamycin. Antibiotic resistance gene such as gyrA, tetA, blaTEM, and ermB were detected in $S$. aureus isolates which isolated from chicken broiler and layer in Bogor Regency

\section{SUGGESTION}

There was still lack of information about antibiotic resistant from $S$. aureus isolated from poultry and layer in Indonesia. Findings in this study indicate that the rate of antibiotic resistant are alarming and increasing. Resistant gene in several isolate in this study are still unclear, therefore similar study can be developed with more additional resistant gene. This study also can be applied in other region in Indonesia to give a national data about antibiotic resistant in Indonesia. Further study may also be done to determine the best solution to manage and reduce antibiotic resistant.

\section{ACKNOWLEDGEMENT}

This research was funded by PMDSU Scholarship Ministry of Research Technology and Higher Education of the Republic of Indonesia.

\section{REFERENCES}

Ali Y, Islam MA, Muzahid NH, Sikder MOF, Hossain MA, and Marzan LW. 2017. Characterization, Prevalence, and Antibiogram Study of Staphylococcus aureus Isolated in Poultry. Asian Pac J Trop Biomed 7(3): 253-256.

Aslam B, Wang W, Arshad MI, Khurshid M, Muzammil S, Rasool MH, Nisar MA, Alvi RF, Aslam MA, Qamar MU, Salamat MKF, Baloch Z. 2018. Antibiotic resistance: a rundown of global crisis. Infect Drug Resist 11: $1645-1658$.

Bermudez AJ. 2003. Principle of disease prevention: diagnosis and control. Ames. Iowas State University Press.
Bianchi DM, Gallina S, Bellino A, Chiesa F, Civera T, Decastelli L. 2014. Enterotoxin Gene Profiles of Staphylococcus Aureus Isolated from Milk and Dairy Product in Italy. Letter Appl Microbiol 58: 190-196.

Bounar-Kechih S, Hamdi MT, Aggad H, Meguenni N, Cantekin Z. 2018. Carriage Methicillin-resistant Staphylococcus aureus in Poultry and Cattle in Northern Algeria. Vet Med Int 1-5.

Carvalho IT, Santos L. 2016. Antibiotics in the aquatic environments: a review of the European scenario. Environ Int 94: 736757.

Chuah LO, Syuhada AS, Suhaimi IM, Hanim TF Rusula G. 2018.Genetic Relatedness Antimicrobial Resistance and Biofilm Formation of Salmonella Isolated from Naturally Contaminated Poultry and Their Processing Environment in Northern Malaysia. Food Res Intl 105: 743-751.

CLSI. 2018. M100 Performance Standards for Antimicrobial Susceptibility Testing. Wayne. PA.

Colom K, Perez J, Alonso R, Fernandez-Aranguiz A, Larino E, Cisterna R. 2003. Simple and Reliable Multiplex PCR Assay for Detection of blaTEM, blaSHV and blaOXA-1 genes in Enterobacteriaceae. FEMS Microbiol Letters 223(2): 147-151.

Dayao DA, Seddin JM, Gibson JS, Blackall PJ, Turni C. 2016. Whole Genome Sequence Analysis of Pig Respiratory Bacterial Pathogens with Elevated Minimum Inhibitory Concentration for Macrolides. Microb Drug Resist 22(7): 531-537.

de Vries, LE, Christensen H, Skov RL, Aarestrup FM, Agerso Y. 2009. Diversity of the Tetracycline Resistance Gene Tet $(\mathrm{M})$ and Identiûcation of Tn916- and Tn5801-like (Tn6014) Transposons in Staphylococcus aureus from Humans and Animals. $J$ Antimicrob Chemother 64: 490-500.

Diarra MS, Malouin F. 2014. Antibiotics in Canadian poultry productions and anticipated alternatives. Front Microbiol 5: 282

Disnak Jabar (Dinas Peternakan Provinsi Jawa Barat). 2018. Buku Statistik Peternakan Tahun 2018. Bandung. Disnak Jabar. 
Ditjen PKH (Direktorat Jenderal Peternakan dan Kesehatan Hewan). 2018. Statistik Peternakan dan Kesehatan Hewan. Jakarta. Kementerian Pertanian Republik Indonesia. Hlm. 1-2.

Ditjen PKH (Direktorat Jenderal Peternakan dan KesehatanHewan). 2018. Berdampak negatif bagi kesehatan, pemerintah larang penggunakan AGP pada ternak. http:// ditjennak.pertanian.go.id/berdampaknegatif-bagi-kesehatan-pemerintah-larangpenggunakan-agp-pada-ternak/ [8 Juni 2018]

Fasihi Y, Saffari F, Ghahraman MRK, KalantarNeyestanaki D. 2015. Molecular Detection of Macrolide and Lincosamide-Resistant Genes in Clinical methicillin-resistant Staphylococcus aureus Isolates from Kerman, Iran. Arch Pediatr Infect Dis 5(1): $1-5$.

Fernandez L and Hancock REW. 2012. Adaptive and Mutational Resistance: Role of Porins and Efflux Pumps in Drug Resistance. Clin Microbiol Rev 25: 661-681.

Giedraitiene A, Vitkauskiene A, Naginiene R, Pavilonis A. 2011. Antibiotics Resistance Mechanisms of Clinically Important Bacteria. Medicina 47: 137-146.

Hakkani MG, Rahman MM, Akter MR, Hossain MK, Nazmi A, Rahman MS. 2016. Isolation and Identification of Microorganisms from Cloacal Swabs in Poultry. Asian Australas J Biosci Biotechnol 1(3): 441-447.

Kadariya J, Smith TC, Thapaliya D. 2014. Staphylococcus Aureus and Staphylococcal Food-Borne Disease: An Ongoing Challenge in Public Health. BioMed Res Intl 2014: 19.

Khodadadi P, Bijanzadeh M, Najafi A, Zarinpour V, Moshfe A, Ansari H. 2016. Antibiotic Resistance and Detection of femA Gene in Staphylococcus aureus Isolates from Raw Milk. Medical Lab J 10: 40-45.

Khusnan, Kusmanto D, Slipranata M. 2016. Resistensi Antibiotik dan Deteksi Gen Pengode methicillin resistant Staphylococcus aureus (MRSA) Isolat Broiler di Wilayah Yogyakarta. J Ked Hewan 10(1): 13-18.
Liyanage GY, Manage PM. 2015. Detection of Tetracycline and Oxytetraxycline Resistant Bacteria and Genes in Effluent Water of Zoological Garden, Sri Lanka. Proceedings of Academics World 12th International Conference, Singapore. 15-19.

Lozano C, Rezusta A, Gomez P, Gomez-Sanz E, Baez N, Martin-Saco G, Zarazaga M, Torres C. 2012. High Prevalence of Spa Types Associated with the Clonal Lineage CC398 among Tetracycline Resistant MethicillinResistant Staphylococcus aureus Strain in a Spanish Hospital. J Antimicrob Chemother 67: 330-334.

Meemken D, Blaha T, Hotzel H, Strommenger B, Klein G, Ehricht R. 2013. Genotypic and Phenotypic Characterization of Staphylococcus aureus from Wild Boars. Appl Environ Microbiol 79: 1739-1742.

Morshdy AEMA, Darwish WS, El-Dien WMS, Khalifa SM. 2018. Prevalence of MultidrugResistant Staphylococcus aureus and Salmonella Enteritidis in Meat Products Retailed in Zagazig City, Egypt. Slov Vet Res 55: 295-301.

Netsvyetayeva I, Fraczek M, Piskorska K, Golas M, Sikora M, Mlynarczyk A. 2014. Staphylococcus aureus Nasal Carriage in Ukraine: Antibacterial Resistance and Virulence Factor Encoding Genes. BMC Infect Diseas 14: 128.

Nouri-Gharajalar S, Onsori M. 2019. Molecular Detection of Antibiotic Resistance Genes in Multidrug-Resistant Staphylococcus Aureus Isolates from Dog Dental Plaque. Bulgarian Journal of Veterinary Medecine 22(4): 419427.

Onaolapo JA, Igwe JC, Bolaji RO, Adeshina GO, Parom SK. 2017. Antibiotics Susceptibility Profile of Staphylococcus aureus Isolated from Poultry Birds in Kaduna, Nigeria. $J$ Clin Microbiol Antimicrob 1(1): 2-6.

Ribeiro CM, Stefani LM, Lucheis SB, Okano W, Cruz JCM, Souza GV 2018. Methicillin Resistant Staphylococcus aureus in Poultry and Poultry Meat: a Meta-Analysis. Journal of Food Protec 81: 1055-1062.

Riyaz-Ul-Hassan S, Verma V, Qazi GN. 2008. Evaluation of three different molecular markers for the detection of Staphylococcus aureus by polymerase chain reaction. Food Microbiol 25(3): 452-459. 
Ronquillo GM, Hernandez JCA. 2017. Antibiotic and syntetic growth promoters in animal diets: review of impact and analytical methods. Food Contr 72: 255-267.

SNI Standar Nasional Indonesia 2332.9:2011. 2011. Cara Uji Mikrobiologi - Bagian 9: Penentuan Staphylococcus aureus pada Produk Perikanan. Jakarta. BSN Indonesia.

Song JH, Chang HH, Suh JY, Ko KS, Jung SI, Oh WS, Peck KR, Lee NY, Yang Y, Chongthaleong A. 2004. Macrolides Resistance and Genotyping Characterization of Streptococcus pneumoniae in Asian Countries: A Study of the Asian Network for Surveillance of Resistance Pathogens (ANSORP). Journal Antimicrob Chemother 53: 457-463.

Takaya A, Kitagawa N, Kuroe Y, Endo K, Okazaki M, Yokoyama E, Wada A, Yamamoto T. 2010. Mutational Analysis of Reduced Telithromycin Susceptible of Streptococcus pneumonia Isolated Clinically in Japan. FEMS Microbiol Letters 307(1): 87-93.

Wang YC, Chan JPW, Yeh KS, Chang CC, Hsuan SL, Lin WH, Hsieh YM, Chen TH. 2010. Molecular Characterization of Enroûoxacin Resistant Actinobacillus pleuropneumoniae Isolates. Vet Microbiol 142: 309-312.

Wongsuvan G, Wuthiekanun V, Hinjoy S, Day NPJ, Limmathurotsakul D. 2018. Antibiotic Use in Poultry: A Survey of Eight Farms in Thailand. Bull World Health Organ 96(2): 94-100.
Xu J, Shi C, Song M, Xu X, Yang P, Paoli G, Shi X. 2014. Phenotipic and Genotypic Antimicrobial Resistance Traits of Foodborne Staphylococcus aureus Isolates from Shanghai. J Food Sci 79(4): M635=M642.

Yang CH, Lee SY, Pan HY, Su PW, Chuang LY. 2017. Prevalece and Molecular Characterization of Plasmid Mediated BetaLactamase Genes among Nosocomial Staphylococcus Aureus Isolated in Taiwan. Trop J Pharm Res 16: 155-160.

Zalizar L, Relawati R, Pancapalaga W. Usage of Antibiotic on Chicken broiler in District of Malang, East Java, Indonesia. 2015. Proceeding of International Seminar "Improving Tropical Animal Production for Food Security" Universitas Halu Oleo. Kendari, Southeast Sulawesi. Pp.158-167.

Zhao Y, Guo L, Li J, Huang X, Fang B. 2018. Characterization of antibicrobial resistance genes in Haemophilus parasuis isolated from pigs in China. PeerJ 6: 1-12.

Zmantar T, Khouidi B, Miladi H, Bakhrouf A. 2011. Detection of Macrolide and Disinfectant Resistance Genes in Clinical Staphylococcus aureus and CoagulaseNegative Staphylococci. BMC Res Notes 4: 453. 